PERSPECTIVA TEOLÓGICA ADERE A UMA LICENÇA CREATIVE COMMONS ATRIBUIÇÃO 4.0 INTERNACIONAL - (CC BY 4.0)

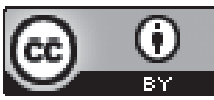

DOI: $10.20911 / 21768757 v 52 n 1 p 187 / 2020$

\title{
FALAR DE DEUS COMO HARMONIA SOBRENATURAL: UM DIÁlOGO ENTRE DAVID TRACY E SIMONE WEIL *
}

\section{God's Talk as Supernatural Harmony: a Dialogue Between David Tracy and} Simone Weil

Tiago de Freitas Lopes **

RESUMO: Este artigo propõe um diálogo entre David Tracy, teólogo da América do Norte, e Simone Weil, filósofa francesa, acerca do falar de Deus. A ênfase consiste na afirmação Trinitária presente nas mediações entre a) Deus e Deus, que revela a mediação intratrinitária, b) Criador e criatura, que revela a mediação entre Deus, a criação e o ser humano e por fim, c) a mediação entre ser humano e ser humano, que necessariamente passa pela Paixão e Redenção. Após uma breve introdução segue uma apresentação dos autores, suas perspectivas sobre o falar trinitário de Deus e por fim, o diálogo propriamente dito. Conclui-se que a amizade que Deus estabelece com o ser humano é um reflexo do relacionamento trinitário no qual Deus, por meio da cruz, no poder do Espírito, revela-se amando e resgatando o ser humano e a criação por meio de uma harmonia sobrenatural.

PALAVRAS-CHAVE: Deus. Trindade. Diálogo. David Tracy. Simone Weil.

ABSTRACT: This article proposes a dialogue on God's talk, between the North American theologian, David Tracy, and the French philosopher, Simone Weil. The emphasis will be on the Trinitarian assertion, present in the mediations between a) God and God, which discloses the intratrinitarian mediation; b) between both

* Este artigo é fruto da Tese Doutoral Falar de Deus: uma conversação entre David Tracy e Simone Weil, defendida em 2019, na Faculdade Jesuíta de Filosofia e Teologia, Belo Horizonte, Minas Gerais, Brasil. O trabalho foi orientado pelo professor Dr. Luiz Carlos Sureki com o apoio da CAPES. A Tese está disponível em: <https://www.faculdadejesuita.edu.br/teses-teologia-227/falar-de-deus-uma-conversacao-entre-david-tracy-e-simone-weil-23012020-115718>.

** Colégio Batista Mineiro, Unidade Betim, Minas Gerais, Brasil. 
Creator and creature, which discloses the mediation between God, the creation and the human being; and finally, c) between human beings, which necessarily passes through Passion and Redemption. After a brief introduction, it will first present both authors and their respective perspectives on God's Trinitarian talk. It will then continue with the dialogue between them. Finally, it will conclude that the friendship God establishes with human beings reflects the Trinitarian relationship in which God, through the cross and the power of the Spirit, reveals himself by loving and rescuing human beings and the creation by means of a supernatural harmony.

KEYWORDS: God. Trinity. Dialogue. David Tracy. Simone Weil.

\section{Introdução}

Galar de Deus envolve duas considerações. A primeira é que só podemos F falar de Deus se, primeiro, Deus nos falar. Ele nos fala por meio da Palavra e do Espírito; quando oramos e esperamos por ele, seja de maneira individual ou comunitária. Ele nos fala de forma graciosa e inesperada. A segunda consideração é a maneira pela qual falamos de Deus hoje. Junto com a Escritura afirmamos que "Deus é amor" (1Jo 4,8.16). O amor de Deus enquanto dom gracioso trinitário vem sobre nós de maneira que dele não temos nenhum controle, nos restando apenas clamar e esperar. Ressaltamos, nesse sentido, a amizade sobrenatural de Deus pelo ser humano, que considera proximidade e distância, termos que são entendidos aqui como harmonia sobrenatural.

Nessas duas considerações levantam-se algumas questões centrais: como podemos compreender a amizade de Deus pelo ser humano e pela criação de maneira trinitária? Como falar de Deus levando em conta a espiritualidade cristã em diálogo com outras percepções a seu respeito? Pensar nisso nos conduz ao horizonte do diálogo. Dialogar é falar por meio do Logos, que na perspectiva cristã, mais do que uma reflexão racional, é o próprio Cristo, o mediador entre Deus e os homens (Jo 1,1; 1Tm 2,3). Dialogar é conversar. E conversar é interpretar! É nesse sentido que se faz relevante uma conversação a respeito do falar de Deus considerando as reflexões de Tracy e Weil.

David Tracy (1939-) é um teólogo cristão católico da América do Norte, professor emérito na The University of Chicago Divinity School. Seu trabalho teológico propõe uma preocupação com o método em teologia (Blessed rage for order); a necessidade de fazer com que o falar de Deus seja proclamado de maneira pública, e não privada em um contexto marcado pelo pluralismo e pela diversidade cultural (A imaginação analógica) e uma preocupação com o pensar Deus na perspectiva contemporânea, considerando a pós-modernidade (Plurality and ambiguity). 
Seu método de estudo denominado "revisionista", de ênfase correlacional, consiste na recuperação crítica da teologia liberal e moderna, corrigindo as limitações teológicas desses modelos, recuperando também o significado dos modelos neo-ortodoxos e radicais da teologia. A noção de publicness ("discurso público") da teologia é central aqui pois o falar de Deus não pode ser restrito à Igreja. Na pesquisa de Tracy há três públicos aos quais um teólogo se dirige: o público "Igreja", que é relacionado à teologia sistemática; o público "universidade", relacionado a uma teologia fundamental e o público "sociedade", que se relaciona com uma teologia da práxis. Em relação à noção de publicness da teologia, mais que um discurso racional e hermenêutico, torna-se necessário um entendimento de Deus que tenha um caráter místico-profético que envolva razão e espiritualidade.

A imaginação analógica surge como uma convicção teológica para interpretar os clássicos cristãos religiosos, abrangendo as realidades Deus-eu-mundo (TRACY, 2006, p. 548-560). Clássicos são entendidos como "aqueles textos, eventos, imagens, pessoas, pinturas e símbolos a respeito dos quais se assume que revelam possibilidades permanentes de sentido e verdade" (TRACY, 2006, p. 110). Para exemplificar, na Escritura e na tradição cristã, o evento e pessoa de Jesus Cristo (e consequentemente a relação trinitária) são Clássicos Religiosos Cristãos. Por possuírem o status de clássicos falam à tradição cristã e a outras culturas e tradições também.

Ao considerar os desafios da pós-modernidade, o autor voltou sua atenção para os temas da alteridade e da diferença. Dessa forma, ao fazer um exercício de revisionismo com sua própria teologia chegou ao entendimento de que a maneira de falar de Deus para os públicos do teólogo (Igreja, universidade e sociedade) é apresenta-lo como amor. Na pós-modernidade, o retorno de Deus não é pelos "ismos" (deísmo, teísmo, panteísmo, panenteísmo, ateísmo), mas por aquilo que é revelado nos escritos joaninos: “Deus é amor"! (1João 4,8.16).

Neste horizonte, sua compreensão trinitária possui como ponto central refletir o que significa "Deus é amor" em relação ao sofrimento de Jesus Cristo (TRACY, 2006, p. 559). Em escritos mais recentes, resgata valores e princípios da espiritualidade trinitária medieval e de Lutero propondo reflexões sistemáticas contemporâneas que possuam um compromisso com uma teologia pública, Trinitária e em diálogos ecumênicos e com outras religiões, sem perder de vista a centralidade da pessoa e evento de Jesus Cristo.

Atualmente, suas pesquisas revelam a importância de pensar por meio de uma teoria dos fragmentos. $\mathrm{O}$ fragmento é uma parte mais ampla da discussão literária, filosófica e, para Tracy (2005a, p. 229), também teológica. Eles têm por objetivo repensar as famosas separações da modernidade: razão e paixão, teoria e prática, forma e conteúdo. Teologicamente, a teoria 
dos fragmentos propõe superar a divisão entre teoria e prática, reunindo teologia e espiritualidade. As teologias políticas, da libertação e feministas são exemplos de como isso pode acontecer.

Simone Weil (1909-1943) foi uma filósofa impactada pela realidade de Deus. O grande mérito da autora, conforme mostramos neste artigo, é o fato de escrever sobre aquilo que experimentou de maneira particular e intensa, como relatou em sua Autobiografia Espiritual: "Cristo se apoderou de mim!" (WEIL, 1987, p. 50-51). Era de ascendência judia. Radicada na França, se dizia mais francesa do que judia. Viveu em um contexto marcado pela Primeira e Segunda Guerra Mundiais e num tempo em que a mulher, enquanto pensadora, não possuía reconhecimento. Weil se tornou uma das grandes filósofas do século XX, levando adiante suas reflexões inquietantes, seus protestos contra a alienação do trabalho e da vida e suas reflexões a respeito de Deus. Atualmente, suas obras podem ser consultadas a partir da edição das Oeuvres Complètes (doravante OC) publicadas pela editora Gallimard.

Simone Pétrement (1997), que se tornou amiga de Weil em 1926 quando estudavam na École Normale Supérieure, a apresenta como uma professora dedicada e atenciosa que ficou conhecida por suas atuações como sindicalista; vivenciando a experiência do trabalho de pescadores, mineiros e no trabalho do campo, nas vinhas. Além disso, trabalhou em fábricas (a exemplo da Renault) onde experimentou a "marca da escravidão". Ela ainda participou ativamente na Guerra Civil Espanhola entre 1938 e 1939; trabalhou em um escritório político da Resistência Francesa ${ }^{1}$ entre 1942 e 1943 e deu vida a projetos de renascimento da Europa, conteúdo exposto em sua obra, L'Enracinement (1997, p. 143-144; 182-183; 199; 671ss).

Weil possuía um gosto pela leitura clássica grega (e por tudo que vinha da Grécia), pela cultura egípcia, pelos pitagóricos, pelo Novo Testamento, em especial a narrativa da Paixão e a oração do Pater Noster (Mt 6, 9-15; Lc11,2-4) além de apreciar textos místicos como os de João da Cruz. Morreu em 1943, diagnosticada de tuberculose e porque se recusava alimentar-se (1997, p. 709, 721-722).

Seu método filosófico considerava a analogia e a contradição para aproximar a Grécia do cristianismo e vice-versa, por meio de um recurso hermenêutico criado por ela, denominado "leitura sobreposta" (que veremos mais adiante). A autora também refletiu sobre doutrinas cristãs como Deus,

\footnotetext{
${ }^{1}$ A Resistência Francesa (1940-1944) foi um movimento formado por franceses que não aceitavam a submissão do Estado Francês ao poder nazista, e que se encontravam desiludidos com Pétain e com a política colaboracionista. A instauração da Revolução Nacional pôs fim aos partidos e aos sindicatos, para servir os ditos interesses "patriotas", forçando os dispersos grupos de resistência a unirem-se na luta contra o inimigo comum, para alcançarem a libertação do país.
} 
Trindade, Graça, buscando novas "leituras" entre a Grécia e os clássicos religiosos do cristianismo.

Na avaliação de Tracy é difícil propor um olhar simples e único para Weil. Ela foi uma das maiores pensadoras religiosas do século XX e suas contribuições para a teologia cristã têm por objetivo "reunir caminhos místicos e proféticos da tradição cristã para constituir uma filosofia e uma teologia mística e profética coerente" (TRACY, 2009, p. 274). Na vida de Weil a teoria não se separa da prática e, por isso, "o pensamento pós-moderno preferiu ver nela um ícone da desmedida" (TRACY, 2014, p. 301). Assim, sempre ao mencioná-la, Tracy deixa explícito que o legado da autora não pode ser reduzido à sua biografia.

A maneira com a qual Weil lidou com a teologia afeta os pontos centrais da doutrina cristã. Deus torna-se para ela escondido e também ausente, como para Lutero. A encarnação, à luz da cruz, assume um sentido kenótico, mas, ao mesmo tempo, torna-se um sinal de contradição. Sua antropologia cristã não se caracteriza pela interpretação tomista da natureza da graça, nem pela interpretação da Reforma em relação ao pecado e à graça. A realidade trágica compreende os aspectos da grandeza e da miséria humana, como em Racine e Pascal. Ela identificou uma espiritualidade grega que não é diferente da espiritualidade cristã. A autenticidade de seus escritos está em suas leituras sobre os gregos e também em suas leituras parciais, porém extraordinárias, do Novo Testamento. (TRACY, 2009, p. 285, 288, 294-295).

O que torna plausível um diálogo entre e com os autores nesse artigo é a abordagem sobre Deus, tendo como eixo central, pensá-lo como amor sobrenatural Trinitário derramado como dom gratuito.

\section{Deus Trinitas: a perspectiva de David Tracy}

Nas reflexões de David Tracy percebemos uma preocupação em trabalhar a questão trinitária. Em uma entrevista concedida a Scott Holland (2002) ele relatou que entre os anos 1992 a 2002 desenvolveu um projeto denominado This side of God, que teve início a partir de palestras de Tracy na prestigiosa Gifford Lectures, Edimburgo, entre os anos de 1999-2000. Esperava-se que o autor publicasse um conjunto de obras que tratassem em um primeiro volume a respeito de Deus enquanto oculto e compreensível-incompreensível. O segundo volume seria a respeito da cristologia e o terceiro volume a respeito do Espírito em diálogos com outras religiões.

Os leitores de Tracy aguardam nos últimos 25 anos essa publicação. A boa notícia é que foi recentemente publicado pela editora da Universidade de Chicago os ensaios de Tracy. O primeiro intitula-se Fragments: The 
Existential Situation of Our Time. O segundo volume dialoga com vários autores, entre eles, grandes pensadores como Agostinho, Lutero e Erasmo, Rahner, Lonergan, Paul Tillich, Reinhold Niebuhr, Iris Murdoch e Simone Weil (WOODWARD, 2019, p. 4-5).

Dos textos publicados a partir de 2002 nota-se que as teologias pós-modernas, lidas por meio do método revisionista, têm conduzido o autor a reflexões mais trinitárias destacando a categoria "Deus é amor" e propondo uma reaproximação entre teologia e espiritualidade. Essa discussão trinitária considera as recuperações da teologia de Guilherme de St. Thierry (1085-1148), teólogo místico, e a compreensão de Deus Theologicus proposta pelo reformador Martinho Lutero (1483-1546).

\subsection{Influências de Thierry: Unitas Spiritus}

Willian St. Thierry (1058-1148) foi um místico e abade em Saint-Thierry que propôs um modo novo de teologia para o século XII. Na pesquisa de Tracy (2012, p. 391ss), St. Thierry desenvolveu uma doutrina da Trindade alicerçada na espiritualidade da inter-relação do amor e da razão de uma nova teologia trinitária. Essa doutrina baseava-se em uma experiência do amor divino e era articulada em três estágios da jornada espiritual e intelectual do teólogo.

No primeiro estágio, o amor é guiado pela ratio fidei para aprender a ler as Escrituras de maneira meditativa. Nesse momento, aprende-se a amar a Deus porque ele nos amou primeiro (1Jo 4,19). O amor também busca a cura dos impulsos, desejos e afeições. A alma (mente e vontade) é purificada e transformada gradualmente em uma alma amorosa que se deleita na presença de Deus.

No segundo estágio encontra-se a relação entre fé e razão e novas formas de discernimento das realidades espirituais nas Escrituras, na liturgia, na oração, oferecendo ainda novas leituras hermenêuticas e meditativas. $\mathrm{O}$ segundo estágio rende-se ao amor. Agora, na ratio fidei, o intelecto descobre que é dirigido pelo desejo do Bem, o amor autêntico de Deus.

No terceiro estágio, denominado sabedoria contemplativa, há uma harmonização que integra razão e amor na alma. A razão se torna mais especulativa e contemplativa e a scientia se rende à sapientia. Sapientia é o amor da sabedoria que agora pode ser provado. Neste estágio a alma entende e experimenta a imago e similitude como uma imago Trinitas e descobre conscientemente e amorosamente que participa do amor que é Deus. Deus amoroso é a Trindade. Essa nova sabedoria amorosa, fruto da graça santificadora do Espírito, a Unitas Spiritus, permite que a alma viva em espírito (TRACY, 2012, p. 396-404). 
A inovação teológica à qual Tracy chama a atenção é de que a alma descobre nesta vida a presença do Espírito, e só então o "self" saberá que sua imago Dei não é apenas a imago construída por uma abertura e capacidade para Deus, mas é algo totalmente inesperado: a alma torna-se imago Trinitas. Foi nesse sentido que St. Thierry "formulou um caminho teológico e espiritual conectado para esclarecer como a crença mais profunda do Novo Testamento: 'Deus é Amor' é a primeira maneira cristã de dizer que Deus é um Deus em três Pessoas divinas" (TRACY, 2012, p. 390). Isso exige uma teologia trinitária nova, comprometida com a graça do amor divino. Essa nova teologia trinitária é, ao mesmo tempo, especulativa, metódica e sistemática, correlacionada à jornada espiritual.

No entanto, Tracy faz uma crítica a St. Thierry. A jornada para a espiritualidade e para a experiência da Unitas Spiritus é, na maioria das vezes, dirigida apenas aos monges. Especialmente em seu texto mais lido, Lettre aux freres du mont-Dieu: (lettre d'or) ${ }^{2}$, a lição que St. Thierry deixa é a de que os "esforços teóricos de um teólogo na teologia trinitária devem ser informados pela prática espiritual, seja essa prática incipiente ou como a de Thierry, explícita, direta e metódica (os três estágios harmonizando fé, amor e razão)" (TRACY, 2012, p. 416).

Distintamente de St. Thierry, Tracy $(2012$, p. 410) não é um místico, mas isso não o impede de ler teologias místicas. $\mathrm{O}$ que fica de desafio para os teólogos é a necessidade de ler, meditar e interpretar os místicos clássicos. Isso também exige que o teólogo leve a sério sua vida espiritual não separando teologia e espiritualidade. O problema neste caso, é que a maioria dos teólogos além de "não místicos" são "não poetas". A reflexão mística e a poesia, na opinião do autor, merecem um lugar especial no labor teológico.

A partir de um diálogo entre os autores podemos considerar que a união da espiritualidade, amor e razão está para uma perspectiva teológica pneumatológica. Isso é um desenvolvimento na teologia de Tracy. Em $A$ imaginação analógica o foco foi pensar uma cristologia, que em nossa análise, pode ser lida como uma "cristologia trinitária", uma vez que todas as doutrinas do Novo Testamento, incluindo a Trindade, passam necessariamente por Cristo. Como ele mesmo destacou, "alegar um cristocentrismo não significa necessariamente optar por uma cristologia exclusivista ou por um cristomonismo" (TRACY, 2006, p. 300).

Assim, pela Unitas Spiritus a presença do Espírito pode ser vivida no horizonte do "já" e do "ainda não" como dom-graça de Deus, fazendo

${ }^{2}$ SAINT-THIERRY, Guillaume de. Lettre aux freres du mont-Dieu: (lettre d'or). Paris: Cerf, 1975. (SC, 223). 
com que o conhecimento de Deus, sua nomeação como "amor" seja a partir de uma vida no Espírito, que é a unidade, harmonia e comunhão do Pai e do Filho. Isso nos leva a compreender que falamos de Deus por meio da Unitas Spiritus. Este falar necessita sair do locus privado religioso e alcançar uma publicness. O ponto de partida para este fazer teológico público ainda permanece sendo a cruz. É por meio dela que temos uma vida no Espírito e só assim é que o falar de Deus pode tornar-se público e alcançar não apenas a Igreja, mas a universidade e a sociedade, como públicos do teólogo. Dessas reflexões surge também a oportunidade de fazer com que o falar de Deus para os públicos do teólogo tenha mais humildade, mais poesia, mais mística e mais beleza.

\subsection{Influências de Lutero: Deus Theologicus como Deus Trinitas}

O entendimento central de reformador Martinho Lutero (1483-1546) sobre o Deus Theologicus aconteceu entre 1514-1546 ao mostrar Deus como revelado pela graça de Cristo, amoroso, gracioso, que está manifestado e, ao mesmo tempo, escondido na revelação da cruz de Cristo. (TRACY, 2015, p. 110-111). Tal "esconder" de Deus aparece no Comentário aos Salmos." Lutero ressaltou a cruz como o lugar de Deus como escondido. Ele assumiu a partir da teologia da cruz de Paulo uma compreensão totalmente nova a respeito de Deus: o crucificado. A revelação de Deus encontra-se sob uma lei, na qual se aprende que Deus revela-se de maneira oculta. Tracy (2005a, p. 241) relata que sobre o Deus escondido não leu nenhum autor cristão compatível com Lutero.

Ao articular o falar de Deus como revelado, sub contrariis, na cruz, Lutero refletiu a partir das cartas do apóstolo Paulo aos Romanos e aos Gálatas. A principal contribuição do reformador foi a de ajudar os cristãos a "verem a natureza infinitamente amorosa de Deus como revelada de forma contraintuitivamente na cruz e entender que Deus não é apenas incompreensível, mas também absconditus" (TRACY, 2015, p. 114-115). Desse modo, Deus é apresentado como escondido, sob a articulação de uma teologia da cruz em que "Deus revela a si mesmo aos seres humanos pecadores sub contrariis: na vida após a morte, na sabedoria mediante a loucura, na força mediante a fraqueza" (TRACY, 2005b, p. 89). Deus escondido não é somente humilde, mas humilhado, Deus incarnatus, Deus absconditus, um tipo de reflexão presente nas teologias políticas e da libertação, em que a importância da teologia da cruz de Lutero é a de revelar Deus no sofrimento dos povos.

Tracy (2015, p. 135-136) assume que ao refletir acerca Deus como oculto-revelado, Lutero poderia estar sustentando um tipo de teologia da justifi-

\footnotetext{
${ }^{3}$ Os escritos a respeito dos Salmos referidos no artigo encontra-se em LUTERO, Martinho. Obras Selecionadas: interpretação Bíblica: princípios. São Leopoldo: Sinodal, 2003. v. 8.
} 
cação como theosis, originado de suas disputas tardias acerca da Trindade. Nelas, Cristo é o primeiro presente do justificado a partir de uma troca maravilhosa: a presença indulgente de Cristo (Cristo pro me), a presença de Cristo "em mim"; e a presença de Cristo "em nós" pelo poder santificador do Espírito. A presença do crucificado encontra diferentes denominações em Lutero, uma vez que a troca que Cristo fez na cruz assume o pecado, a maldição, o abandono por Deus, enquanto que nessa mesma troca encontra-se a conquista justificadora da sabedoria de Cristo.

Com isso, o Deus Theologicus era, firmemente, o Deus Trinitas que se revela por meio de sua face abscôndita uma vez que pensar Deus como "escondido" inclui os sofrimentos, conflitos e estranhamentos que se encontram no "self", "desde Paulo, passando por Agostinho, Lutero, Kierkegaard, chegando até as teologias existencialistas de nosso tempo" (TRACY, 1993, p. 126).

Há uma insistência de Tracy (2005b, p. 88) em afirmar que na história moderna Deus muitas vezes não passa de algum "ismo" disfarçado, que remonta a uma parte de Deus importante (teísmo e panteísmo modernos), outras vezes, um aparte que falta (ateísmo ou agnosticismo). Contudo, o senso da modernidade em sua própria continuidade e confiança foi abalado pela irrupção de um sofrimento global na história moderna, uma vez que a presença de um sofrimento global maciço revela a realidade dos outros e dos diferentes. Então, Deus entra na história não mais como um "ismo" consolador, nem como uma nova especulação, mas como o Deus oculto, imprevisível, libertador, incompreensível, pois Deus revela-se como absconditus nos místicos, na religião do povo, na cruz e na negatividade.

As contribuições da teologia de Tracy neste horizonte denotam que a maneira de percebermos a autocomunicação de Deus se faz por meio de sua presença na ausência. Essa manifestação se dá na cruz, lugar onde Deus se revela a partir de uma contradição colocada por Paulo: o poder que se revela na fraqueza (2 Co 12,9). O poder de Deus, considerando a kenosis, torna-se um "não-poder" (como pensava Simone Weil) pois o dom gracioso sob a cruz é o maior bem que temos de Deus. Dessa maneira, o lugar que Deus quer nos encontrar é na cruz, onde precisamos morrer para viver (Fl 1,21). É notável que Tracy apresenta nas últimas duas décadas uma teologia mais explicitamente trinitária do que em suas obras Blessed rage for order e $A$ imaginação analógica. Ele percebeu que no tempo presente (que muitas vezes ele chama de pós-modernidade) o falar de Deus necessita ser trinitário porque é dessa maneira que o amor de Deus se apresenta.

É também muito significativo que o referido teólogo buscou aportes na teologia católica (Thierry) e na teologia protestante (Lutero) para resgatar compreensões trinitárias do amor de Deus. Isso faz parte de uma imaginação analógica e do método revisionista. Essa proposta ecumênica, 
tão necessária para nossos dias é um caminho para que o falar de Deus encontre ecos mais públicos retomando as trajetórias da manifestação e da proclamação. Como Tracy (2006, p. 288) insistiu em A imaginação analógica, não há manifestação (tradição católica, ênfase no sacramento) sem proclamação (tradição protestante, ênfase na palavra) e vice-versa. É com tal compromisso que o falar de Deus Trino em sua dimensão de revelação-ocultamento ganha contornos mais públicos e mais místicos-proféticos na teologia de Tracy.

\section{A Trindade como harmonia sobrenatural: a perspectiva de Simone Weil}

Weil tinha uma maneira singular de pensar a Trindade: como harmonia feita por meio da amizade e da distância. Ela considera duas fórmulas pitagóricas de Filolau: "a harmonia é a unidade de uma mistura de vários, e o pensamento único dos pensantes separados" e "a amizade é uma igualdade feita de harmonia" (WEIL, 2006, p. 165; WEIL, OC IV, 2, p. 262). Essas fórmulas são repletas de significados que dizem respeito a Deus e à relação entre Ele, a criação e o ser humano. É nesse momento que o conceito de mediação é fundamental para a compreensão de harmonia.

O tema da mediação possui aqui dois sentidos. O primeiro sentido é aquele formulado pela tradição pitagórica visto como princípio da constituição ontológica do mundo. O segundo sentido é de ordem teológica e considera ter um princípio secreto de mediação, a imagem de uma mediação trinitária que transcende o mundo. Em Marseille, Weil desenvolveu uma ontologia da mediação que insistia que "cada realidade criada pelas 'relações' que a constituem assim como pelo 'vazio', que a abrem para lá dela mesma, é um metaxu (intermediário), uma passagem para Deus" (GABELIERRI, 2009, p. 113). "Em um mundo em que coexistem diferentes planos da realidade é necessário haver passagens que permitam a interconexão entre os diversos domínios" (PUENTE, 2013, p. 164). Esses planos devem ser interpretados por meio de uma sucessão de "leituras sobrepostas". Dessa maneira, a leitura implica

ler Deus em toda manifestação, sem exceção, mas segundo a justa relação da manifestação própria de cada aparência. Saber de que maneira cada aparência não é Deus. Fé, dom da leitura. O dom da leitura é sobrenatural e, sem esse dom, não há justiça. (WEIL, Cahier V [K5] apud VILELA-PETITI, 2014, p. 216, tradução nossa).

As leituras sobrepostas consistem em "ler a necessidade por trás da sensação, ler a ordem por trás da necessidade e ler Deus por trás da ordem" (WEIL, OC VI, 2, 373). A necessidade por trás da sensação ressalta a miséria 
humana e está presente na Ilíada e nas Tragédias Gregas. A ordem por trás da necessidade revela a ordem/beleza do mundo, no Timeu e no Banquete. Ler Deus por trás da ordem revela a transcendência percebida pela autora em textos como República, Fedro, Teeteto, Górgias e nos pitagóricos.

As leituras sobrepostas também marcam os três momentos do platonismo de Weil. O primeiro momento mostra a necessidade de uma salvação sobrenatural, a ideia de uma assimilação a Deus, fundada na oposição das duas morais: aquela que é deste mundo, das recompensas aparentes e a outra, a moral sobrenatural, que remete ao justo crucificado (República, II, 360ss). O segundo momento do platonismo refere-se à experiência da graça e simboliza a saída da caverna (República, VII, 514âa-516c), lido à luz de João da Cruz. Nessa experiência, o prisioneiro é liberto (noite da sensibilidade) e, ao sair da caverna, recebe o choque de luz (noite do Espírito). Depois, passa-se à contemplação do sol (relativo ao casamento espiritual proposto por João da Cruz). O terceiro momento do platonismo de Weil é o retorno à caverna, quando o prisioneiro, após ter atravessado a morte para ir até Deus, volta à caverna para refletir a luz sobrenatural. (GABELIERRI 2003, p. 308-312; WEIL, 2006, p. 67-140).

A necessidade e a beleza do mundo revelam Deus como gracioso e como um bem que não pode ser dominado, mas esperado. A necessidade para a autora não é "falta". "É o véu de Deus [...]. A distância entre o necessário e o bem é a própria distância entre a criatura e o criador" (WEIL, 1993, p. 113).

A espera (gr. upomoné), "designa um homem que espera sem se mover, apesar de todos os golpes com os quais se trata de fazê-lo abandonar esse estado de quietude." (WEIL, 1991, p. 142). A espera é explicada por meio da seguinte analogia: uma criança que na rua subitamente deixa de ver sua mãe a seu lado. Essa criança corre em todas as direções chorando. A única solução que ela tem é a de deter-se e esperar, até que sua mãe a encontre o mais depressa possível. Só é preciso esperar e chamar (WEIL, 1991, p. 46).

Ler Deus por trás da ordem/beleza do mundo conduz ao que Weil chama de não-leitura: perceber Deus no silêncio. E para isso torna-se necessário da parte do ser humano, uma renúncia do eu, de suas leituras, para que Deus possa preencher o vazio, a "noite escura" (em referência a João da Cruz). Aceitar o vazio é algo sobrenatural, uma vez que Deus é quem lança o ser humano no vazio e é ele mesmo quem também o preenche. Somente a graça pode suportar e preencher o vazio (WEIL, 1993, p. 12).

Deve-se ainda ater-se à contradição entre a gravidade e a graça. A gravidade é a nossa baixeza, a força que nos faz descer, um movimento natural da alma. É o que nos prende a este mundo. Está ligada ao poder e à glória 
que o ser humano é exposto. Se a gravidade nos puxa para baixo, a graça nos puxa para cima. Ela vem de Deus, de maneira sobrenatural para nós. É uma dádiva sobre a qual não temos nenhum controle, tornando-se o bem pelo qual todos nós podemos esperar (WEIL, 1993, p. 1-4).

Do ponto de vista da graça como uma dádiva sobrenatural, todas as coisas são um reflexo de Deus, o qual, como Trindade, é a mediação perfeita; pela Encarnação se revela ser a relação, o Mediador, sem o qual "não se pode passar de nada a nada." (WEIL, OC IV, 2, p. 289). "Deus é mediação e toda mediação é Deus. Deus é mediação entre Deus e Deus, entre Deus e o homem, entre o homem e o homem, entre Deus e as coisas ${ }^{4}$, entre as coisas e as coisas, e mesmo entre cada alma e ela mesma".

É a partir desse raciocínio que se pode evidenciar as mediações entre Deus e Deus, como o primeiro par de opostos que revela a relação intratrinitária; Criador e criatura, o segundo par de opostos, que ressalta a beleza do mundo (Deus e o mundo) e a relação Deus e o ser humano. Por fim, o terceiro par de opostos, a relação entre os seres humanos, a qual só é possível se passar por Deus. Essas três mediações encerram as relações que envolvem amizade entre as pessoas e são o interesse deste artigo.

Partindo desses pressupostos, há dois aspectos da amizade como reflexo gracioso da Trindade que precisam ser considerados: a proximidade (no sentido de igualdade) e a distância (no sentido de diferença). "Só há amizade onde a distância é conservada e respeitada" (WEIL, 2005, p. 201). Isso faz com que haja uma extrapolação dos sentidos mais tradicionais que a teologia cristã atribui aos conceitos de philia e ágape.

Teologicamente o amor trinitário de Deus estabelece-se não apenas como amizade (philia), mas como ágape. A língua grega extrabíblica tem várias palavras para significar a concepção de amor. Phileo é uma palavra mais generalizada para "amor", considerada como "afeição". Ela denota em especial a atração de pessoas entre si quando estão vinculadas dentro ou fora da família, o que inclui preocupação, cuidado e hospitalidade. As ideias que se vinculam com phileo "não possuem ênfase claramente religiosa" (COENEN; BROWN, 2000, p. 113).

Agapao e ágape aparecem frequentemente como alternativa ou sinônimo para phileo. Ágape corresponde a uma iniciativa generosa de uma pessoa por amor a outra. Diferente de eros, não se refere a qualquer tipo de anseio

\footnotetext{
${ }^{4}$ A harmonia que há entre as coisas não constitui uma amizade. Contudo, nesse nível deve-se compreender que todas as coisas são formadas por um "número", um tipo particular de correlação entre o limite e o ilimitado. Deus é o princípio de toda limitação. A criação é matéria ordenada por Deus. A ação de Deus é impor limites. Esses limites são análogos à quantidade. Em um sentido mais amplo, pode-se dizer, por meio da teoria da mediação pitagórica, que o limite é o número. (GABELIERRI 2003, p. 320-321).
} 
humano por posse ou valores. Na perspectiva da teologia do Novo Testamento, o amor é uma das ideias centrais que expressam o conteúdo total da fé Cristã (Jo 3,16) no qual, a atividade de Deus é o amor que procura o ser humano (1Jo 4,8.16) (COENEN; BROWN, 2000, p. 117).

Apesar de haver uma distinção entre phileo e ágape em Jo 3,35; 5,20, esses termos são empregados como sinônimos do amor do Pai para com o Filho, como em Jo 21,15 quando Jesus pergunta a Pedro se ele o amava. Nos escritos joaninos, Deus é essencialmente amor (1Jo 4,8.16) e seu propósito é o amor desde o princípio. Dessa maneira, o amor do Pai para com o Filho é o arquétipo de todo amor (COENEN; BROWN, 2000, p. 120).

Tornar-se amigo de Deus é ser amado por ele incondicionalmente. Entretanto, o amor de Deus por nós acontece por uma mediação da harmonia sobrenatural. A conexão para essa harmonia, a mediação, é o Cristo e não o ser humano. Dessa forma, Deus nos atrai à amizade mediante uma harmonia sobrenatural. O grito de angústia do crucificado, "Deus meu Deus meu, por que me abandonaste?" (Mc 15,34) revela um aspecto dessa harmonia: a presença na distância e no ocultamento. "A palavra secreta de Deus é o silêncio. [...] Cristo é o silêncio de Deus." (WEIL, 1991, p. 105). Esse silêncio, quando entendido por meio da atenção, penetra a alma, fazendo que a espera tenha um sentido esperançoso. É nesse sentido que a Trindade é uma mediação perfeita conquanto nos alcance mediante uma amizade sobrenatural que é ao mesmo tempo, distância, espera e presença.

\section{Um diálogo acerca da Trindade}

Após apresentar algumas considerações trinitárias das percepções de Tracy e Weil passaremos a um diálogo com e entre os autores evidenciando a) a mediação entre Deus e Deus; b) a mediação entre Criador e criatura e c) a mediação entre os seres humanos, que passa necessariamente por Deus. O ponto fulcral do diálogo considera que a percepção trinitária de Tracy insere-se nas relações ordenadas Deus-eu-mundo. Isso porque a espiritualidade, o amor e a razão não podem ser desvinculados da esfera relacional na qual vivemos. As mediações propostas por Weil também consideram o ambiente relacional. Portanto, para os dois pensadores, a realidade trinitária não pode ser desvinculada das relações que temos com Deus, com o mundo, conosco e com os outros.

\subsection{A mediação entre Deus e Deus}

Teólogos medievais e Lutero ensinaram que a nomeação de Deus acontece de uma forma sobrenatural, racional, amorosa e mística. O texto comumente utilizado pela teologia cristã para salientar a nomeação de Deus 
no Antigo Testamento, (Êx 3,13-14), deixa evidente que a ação graciosa e salvadora vem unicamente Dele, o "EU SOU". O Antigo Testamento revela a santidade de Deus como um bem que o ser humano não pode possuir nem dominar, mas pode participar por meio de uma relação que é, ao mesmo tempo, proximidade e distância. Textos como Lv 20,26, dentre outros, declaram: "Pertencei a mim, santos como eu sou santo, eu, o Senhor [...]". Lemos também na primeira epístola de Pedro: "assim como é santo aquele que vos chamou, também vós tornai-vos santos em toda a vossa conduta" (1Pd 1,15).

Podemos questionar até que ponto a compreensão da mediação proposta por Weil, baseada em suas leituras sobrepostas, nas reflexões pitagóricos e de seu platonismo dialogam com a perspectiva teológica cristã trinitária. Os clássicos da cultura e da filosofia (a exemplo dos textos pitagóricos), assim como os clássicos religiosos cristãos (a Bíblia e a tradição cristã), possuem uma pretensão de verdade. No entanto, os clássicos religiosos cristãos, conforme pensa Tracy, são sui generis. Eles têm uma pretensão de verdade religiosa. Partem da revelação de Deus em Cristo, no poder do Espírito.

A teologia é um ato segundo. $\mathrm{O}$ ato primeiro é sempre a experiência de Deus. Essa experiência está revelada na Trindade. Na nomeação de Deus não há nomes, por mais sublimes que sejam (como ressalta o Pseudo-Dionísio em sua Teologia mística), que definam o amor trinitário. Para os teólogos medievais a teologia mística constituía-se em um caminho para falar analogicamente de Deus. Para teólogos como Lutero, que considerava as leituras de St. Thierry, Deus se revela na cruz, ao mesmo tempo, oculto e revelado.

A compreensão teológica do amor trinitário que Weil percebeu nos pitagóricos como sendo a mediação entre Deus e Deus converge especialmente em um ponto com a teologia: Deus, e somente Deus, por meio de sua graça, vem ao ser humano. Revela-se. Contudo, ao mesmo tempo, impõe um limite, uma distância, uma diferença.

As leituras sobrepostas neste caso enriquecem a teologia. O clássico religioso cristão pode dialogar com o clássico cultural e filosófico grego e vice-versa, uma vez que a mensagem cristã não é exclusivista e isolada e, por isso, o Deus Trino, que se revela na Palavra e no Espírito, estende sua graça a outras culturas. Isso requer que a teologia não restringe o Deus Trino a conceitos, mas compartilhe dele como graça. Outra contribuição de Weil à teologia é pensar Deus ao mesmo tempo como pessoal e impessoal:

Deus é ao mesmo tempo pessoal e impessoal. É impessoal no sentido de que sua maneira infinitamente misteriosa de ser uma Pessoa difere infinitamente da maneira humana. Só se pode compreender esse mistério empregando ao mesmo tempo, como as duas hastes de uma pinça, essas duas noções contrárias, 
incompatíveis neste mundo, só compatíveis em Deus. [...] Só se pode pensar Deus ao mesmo tempo, não sucessivamente, como três e um [...] pensando-o ao mesmo tempo como pessoal e impessoal. Caso contrário representa-se ora uma só Pessoa divina, ora três Deuses (WEIL, 2016, p. 22).

Compreender a Trindade é reconhecer ao mesmo tempo a amizade (Deus como pessoal) e a distância (Deus como impessoal). O que constitui uma esperança graciosa nessa conversação é que Deus toma a iniciativa em nos buscar: "não fostes vós que me escolhestes, mas eu que vos escolhi." (Jo 15,16). Nessa busca, na cruz, Deus revela-se como amor sobrenatural, despojando-se de sua glória, como descrito no Hino de Filipenses 2,7. Weil (1993, p. 133) compreendia que "só podemos saber uma coisa de Deus: que ele é o que não somos. Só nossa miséria é a imagem dele. Quanto mais a contemplamos, mais o contemplamos". Deus é, nesse sentido, pessoal e impessoal.

A mediação entre Deus e Deus ajuda ainda a pensar acerca do mistério divino apofático no qual Deus se dá a conhecer por meio da ausência e da negatividade, o que podemos chamar aqui de distância. Só Deus pode dizer de si mesmo. Só Deus pode amar Deus. Só Deus pode dizer "EU SOU” - ressalta Weil (WEIL, 1985, p. 137).

A ausência de Deus é uma maneira de perceber sua revelação apofática. Não há uma voz, um sinal, ou algo parecido. Mas essa ausência não significa abandono. Significa espera. E como lemos na poesia dos Salmos: "Por que te curvas, minh'alma, e gemes sobre mim? Espera em Deus! Sim, eu ainda o celebrarei, a ele e a sua face salvadora" (S1 42,6; 43,5).

A espera é um elemento central nesse diálogo. $\mathrm{O}$ ser humano espera por Deus porque Ele vem como amor gracioso, como alimento e energia. Precisamos esperar. Mas como esperar em Deus que está oculto e incompreensível? As respostas dos teólogos elucidados e de Weil eram o silêncio, a contemplação e a espera. Por isso, na relação entre Deus e Deus o que cabe ao ser humano é esperar que Deus nos busque e aprender com essa unidade trinitária, um exemplo de comunhão verdadeira.

Tracy entende que as interpretações de Weil do Novo Testamento impactam a forma de pensar as doutrinas clássicas da teologia. Filósofos como Vetö (1997, p.9-17) sustenta que os escritos de Weil poderiam ser interpretados a partir de uma "metafísica religiosa". Gabalierri (2003, p. 307-374) entende em Weil um "platonismo cristão" e uma filosofia da mediação e do dom que dialoga com o cristianismo. Fernando Puente (2013) tem insistido nas leituras do mundo grego feitas pela filósofa, as quais também podem dialogar com o cristianismo. Já a teóloga Maria Clara Bingemer (2009, p. 250), assume que Weil possuía uma paixão pela cruz e notadamente, se considerava cristã. Fato é que as interpretações, fruto das leituras sobrepostas de Weil carrega muitos pontos que podem dialogar com a teologia. Mesmo com os aportes desses pensadores, continua sendo difícil classificar os escritos de Weil como teológicos, uma vez que ela se intitulava uma filósofa. 
Em nossa reflexão, precisamos ponderar uma questão. Se o falar de Deus possui como prerrogativa ter a experiência de Deus, os escritos de Weil estão qualificados para a reflexão teológica. Não na categoria dogmática/ sistemática, mas na categoria de escritos filosóficos que falam de Deus e da tradição cristã. Pensando no diálogo com Tracy, o que qualifica os escritos e a pessoa de Weil é o fato de serem contados na categoria de "clássicos". Clássicos transformam a vida dos leitores. Levam ao inabitual, a pensar de maneira desfamiliarizada e assim, oferecem novas interpretações que causam novos olhares. Partindo desses pressupostos, o falar de Deus na vida e escritura de Weil oferece ao fazer teológico novos prismas para que doutrinas centrais como Deus, Cristologia e Trindade possam ser pensados.

\subsection{A mediação entre Criador e criatura}

A mediação entre Criador e criatura é apresentada por meio de dois aspectos: a beleza do mundo e o vínculo entre Deus, a criação e o ser humano. A beleza é o que faz aparecer o transcendente a nossos sentidos, pois o belo é pensado como um atributo de Deus. "A beleza do mundo é o sorriso da ternura de Cristo para nós por meio da matéria. O amor a essa beleza procede de Deus descendido em nossa alma e vai até Deus presente no universo. Isso é também algo como um sacramento" (WEIL, 2005, p. 154).

A respeito da beleza, Weil (2005, p. 155-156) apresenta uma analogia: dois pássaros estão sobre o ramo de uma árvore. Um come o fruto. O outro apenas olha. A reflexão que se pretende é de que a beleza é uma promessa e não um bem de consumo. E algo que devemos contemplar e esperar, não aquilo que podemos dominar e tomar como nosso.

Tem-se percebido que o positivismo científico ocidental, salienta TRACY; Lash (1985, p. 123), fez com que a compreensão de beleza do mundo passasse a uma interpretação sem poesia, em que o "domínio" tomou o lugar da "beleza". Por isso, muitos teólogos do século XVIII, por causa da antropologização e da privatização da pesquisa teológica, centraram-se na doutrina da redenção, negligenciando a doutrina da criação. Ao considerar a mediação entre Criador e criatura como harmonia sobrenatural, o fazer teológico não pode estar alheio às questões cosmológicas. O tema da criação na teologia contemporânea, não pode ser apenas um argumento alinhado à providência divina, mas uma reflexão trinitária, amorosa e bela a respeito do agir de Deus enquanto criador.

Weil encontrou no Timeu de Platão, que estabelece um modelo explicativo do mundo, uma forma de interpretar a história da criação em perspectiva trinitária: o Pai é o "Criador", e não um mero "demiurgo"; o Filho a "Alma do mundo" e o Espírito o "Modelo". Toda criação passa por Deus e isso é uma iniciativa transcendente, intratrinitária e ao mesmo tempo graciosa. 
O ser que Platão nomeia como "Alma do mundo" é para Weil (OC IV, 2, p. 165) uma alusão ao Filho único de Deus. Da tradução do Timeu 30b-31-b, ela destaca a palavra "monógenis" ("unigênito", "único") para identificar o Cristo, tal como em João 3,16 ao falar do "Filho Unigênito" (vıov avtov

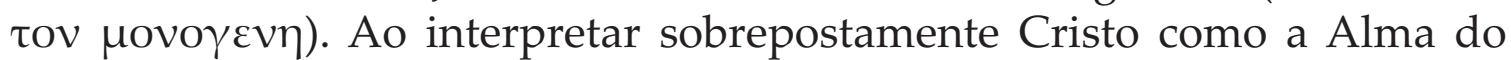
mundo, ela entende que o mundo visível é seu corpo e que isso é mais que qualquer panteísmo. O Filho, como Alma do mundo, governa, comanda, está presente e é maior do que a matéria. Ele não é um demiurgo. É a própria beleza, o próprio Deus criador que contém em si a substância de Deus. A partir desses discernimentos, "o Modelo semelhante ao que gerou a Alma do mundo é um vivente espiritual ou um espírito vivente" (WEIL, OC IV, 2, p. 166). Sendo assim, a Alma do mundo é uma pessoa, e espírito perfeito em todos os aspectos. É Deus. O Filho Unigênito é Deus feliz e têm em si a vida abençoada da Trindade.

Na avaliação de Tracy; Lash (1985, p. 129), a Encarnação do Filho é modelo para nossa encarnação: viver na perspectiva de Deus, a partir de uma entrega total e obediente que só pode ser devidamente interpretada ao assumir uma vida de discipulado, uma imitatio Christi. Nesse discipulado, a cruz se intromete em todo otimismo que permeia o "ainda-não": o sofrimento e a tragédia no âmago de toda a existência humana. Dessa maneira, a ressurreição revela a realidade da esperança frente à natureza e à história, afirmando que Deus atua por meio do ministério da cruz de Jesus Cristo, que continua a oferecer o prisma decisivo para a interpretação cristã: Deus, mundo e ser humano; natureza e história; criação e redenção. Considerar a criação e a redenção nos leva a pensar em uma teologia da criação vinculada à poesia. Em textos bíblicos, a exemplo dos Salmos, dos textos sapienciais, dos Evangelhos, dos profetas, de Jó, é possível identificar uma visão poética da criação. Falar de criação e redenção evoca, na perspectiva cristã, a encarnação.

Entre os autores há percepções muito significativas para a teologia cristã. Ao refletir que a revelação divina está presente em outras culturas podemos entender que "Cristo é tudo e está em todos" $(\mathrm{Cl} 3,11)$. Ele não nos pertence nem o dominamos. Nós é que pertencemos a Ele. Em uma bela passagem de Carta a um religioso, Weil (2016, p. 10) insiste que quando há uma relação entre Deus, que é sobrenatural, e o ser humano, a cronologia não é determinante. E o que isso significa? Que o controle da revelação de Deus vai além de nossas reflexões racionais. É graça! É mistério que nos faz calar. Por isso, ao conectar a beleza do mundo com a teologia compreende-se que a redenção é destinada ao ser humano em suas diversas culturas e a toda criação.

Tracy e Weil são exemplos de pensadores que estão fora da "forma" exclusivista da teologia e da filosofia, encorajando a teologia cristã a perceber a revelação de Deus com mais beleza, mais espiritualidade e mais diálogo. 
Nas relações que abrangem as realidades Deus-eu-mundo, a mediação entre Criador e criatura, aprendemos que a Trindade revela-se como beleza que conduz, nessa relação, comunhão, cuidado e acolhimento para o ser humano e para toda a criação. É a certeza de que Deus não nos deixa sozinhos. A Trindade é reflexo e presença de Deus trino como doador da vida. A harmonia sobrenatural neste caso, se dá na relação em que Deus busca o ser humano. A ligação entre Deus-eu-mundo acontece não por iniciativa humana e imanente, mas descende de Deus como amor e beleza graciosa. Iniciativa em criar e também iniciativa em redimir.

A exigência que essa relação sobrenatural nos pede também é clara: precisamos contemplar mais do que dominar. Precisamos estar em silêncio para que o Deus Trino encha nosso mundo e nossa alma dele. É dessa maneira que vivenciaremos uma encarnação verdadeira, capaz de despojar-se do poder e da glória para viver em comunhão com a Trindade.

\subsection{A mediação entre o ser humano e seus semelhantes}

Este nível de medição considera a amizade entre o ser humano e seus semelhantes. Essa relação só é possível se passar por Deus, o que retoma a importância da relação Deus e ser humano (Criador e criatura). As relações humanas são de força e subordinação, voltadas para a gravidade. Weil considerava que a Ilíada, juntamente com as tragédias de Eurípedes, Sófocles e Ésquilo expunham o drama da humanidade submetida ao império da força: aquilo que transforma os homens em uma coisa, em um cadáver, como ela bem explicitou no texto A Ilíada ou o poema da força:

O verdadeiro herói, o verdadeiro objeto, o centro da Ilíada é a força. A força que é manipulada pelos homens, a força que submete os homens, a força perante a qual a carne dos homens se retrai. [...] A força é o que torna quem lhe é submetido numa coisa. Quando é exercida até ao extremo, faz do homem uma coisa no sentido mais literal porque faz dele um cadáver. Havia alguém e num instante, não há ninguém (WEIL, 2006, p. 9).

Para vencer o império da força e criar um amor verdadeiro, a solução é "reconhecer que nada do mundo é o centro do mundo, que o centro do mundo está fora do mundo, e ninguém aqui em baixo tem o direito de dizer eu" (WEIL, 1985, p. 135). Mais uma vez: só Deus pode dizer "EU SOU". É impossível amar os outros verdadeiramente sem a mediação do amor sobrenatural. Se a amizade é estabelecida pela distância e por meio da espera, a harmonia sobrenatural implica amar nessa distância. A revelação divina não é medida pela busca do ser humano por Deus, mas pela revelação graciosa de Deus ao ser humano. Deus é quem se dá a conhecer primeiro.

Há, nesse sentido, uma contradição entre amizade e distância, presença e ausência que nos leva a refletir que conhecer a Deus em sua distância e 
em sua ausência significa que a percepção Dele está no âmbito da graça redentora que se manifesta na harmonia sobrenatural da amizade. $\mathrm{Na}$ distância infinita entre Criador e criatura, há uma iniciativa graciosa infinita, na qual a mediação entre Deus e Deus é compartilhada agora entre Deus e o ser humano.

Para vivenciar a experiência de Deus torna-se necessário recuperar o sentido da encarnação, Paixão, ressurreição e segunda vinda. Cristo, ao assumir a condição humana, fez mediação entre nós e Deus. Ele nos justificou. Sua Paixão levou para o Pai uma relação entre o sobrenatural, o humano e seus semelhantes, que acima de tudo entrega a vida pelos amigos (Jo 15,3). Dessa maneira, a Paixão revela a esperança da Redenção, que vem de Deus, antes da fundação do mundo e que trinitariamente é a "pura beleza", o "verdadeiro próximo" e o "amigo por excelência" (WEIL, 2005, p. 208-209).

A partir dessa harmonia sobrenatural o poder da cruz se mostra sub contrariis: a vida mediante a morte, a glória mediante a fraqueza. Essas reflexões são oportunas para propor à teologia que o falar de Deus passa pela contradição: a presença e a distância-ausência dele. Sem a vivência da experiência de Deus a teologia se tornará mais uma reflexão acadêmica que não entende a vulnerabilidade e as dores humanas. Em muitas ocasiões, esses aprendizados vêm por meio do silêncio, das "trevas numinosas"; da "noite escura da alma", da realidade sub contrariis da cruz, da experiência de "sair da caverna", formas através das quais Tracy e Weil falaram da espera e do puro dom de Deus que vem até nós como graça.

A harmonia entre Deus e o ser humano que faz possível a relação entre o ser humano e seus semelhantes, tem por fundamento a experiência trinitária, mediada pela cruz. Cabe então à teologia e à Igreja passarem da inspiração à prática cristã, principalmente no que diz respeito ao exercício da alteridade e da hospitalidade para com os outros, especialmente aqueles que estão submetidos ao império da força

Tracy e Weil concordam que necessariamente, a mediação entre os seres humanos, passa por Deus. Quando essa relação não adquire o conhecimento sobrenatural, ela volta-se para a "força", em que o mais importante é o eu, o self egoísta que olha apenas para si mesmo e para suas metanarrativas como Tracy tem destacado em seus escritos. No contato com o conhecimento sobrenatural, com a experiência de Deus, a relação entre o ser humano e seus semelhantes submete a força à uma mortificação, um esvaziamento, que Weil chama de "decriação", e Tracy, "morte do sujeito moderno" na qual se aprende que o centro do mundo é sobrenatural, está fora do mundo. O centro do mundo é Deus-Trino.

É visível na teologia de Tracy um apelo a que a teologia se esvazie de sua "força". Ao reconhecer as teologias latinoamericanas, negras e feministas, 
o autor admite a necessidade de uma readequação no foco que ele mesmo sentiu necessidade. Por isso ele se voltou, em seu projeto teológico, para o outro e para o diferente. Neste horizonte, o papel de uma teologia pública implica no compromisso não apenas com um conhecimento racional e hermenêutico, mas também com uma sensibilidade místico-profética em que o teólogo, tal qual os profetas do Antigo Testamento, levantam-se como uma voz de anúncio da esperança e denúncia contra a força que manipula, aliena e destrói.

Portanto, no diálogo entre os autores fica nítida a urgência de passar da força ao esvaziamento, do orgulho à humildade. Mais do que um esforço humano, essas passagens se dão por meio de um conhecimento sobrenatural, de uma experiência trinitária de Deus. É a essa experiência que somos convidados a participar.

\section{Conclusão}

Deus se dá a conhecer pela harmonia sobrenatural que há na amizade, por meio da contradição entre a presença e a ausência-distância. Pensar a realidade trinitária de Deus a partir desses pressupostos ajuda-nos a compreender que sua presença é puro dom e que o seu conhecimento está espalhado em outras culturas e não apenas na cultura cristã. Pensar sobrepostamente a Trindade e os clássicos gregos conforme apresentado no artigo é algo estranho que Weil faz. Contudo, isso não desqualifica o seu pensamento. Pelo contrário, deve-se levar em conta que as leituras sobrepostas oferecem uma oportunidade para propor novas interpretações do cristianismo e também do mundo grego.

Faz parte da missão cristã, proclamar o Evangelho de Cristo (Mc 16,15; Mt 28,19) até que ele venha. Contudo, isso não significa que sua revelação esteja submetida ao proclamador. Ela é a própria Palavra, a própria proclamação, luz para os perdidos, esperança para os indefesos. Cabe a nós, como arautos, proclamar o quanto pudermos. Entretanto, é necessário reconhecer que a obra da redenção é graça trinitária e não um esforço humano.

Dessa maneira, a Palavra e o Espírito de Deus não são meros produtos do conhecimento cristão. Palavra e Espírito revelam a autocomunicação de Deus que se dá trinitariamente. Juntamente com Tracy podemos assumir que o falar trinitário proclamado pela teologia não é um discurso classicista, mas um clássico, e dessa forma, público. Os clássicos podem transformar a esfera da cultura, da tecnociência e da política. Diferentemente, o discurso classicista está disponível apenas às "elites". A mensagem de Deus ao mundo é proclamada por meio dos clássicos, e não de discursos 
classicistas. Isso nos leva a refletir sobre como a proclamação do Evangelho tem sido feito pela Igreja e pela teologia cristã. Nossa esperança é que seja de maneira pública, e não classicista.

É importante ressaltar que para Tracy o clássico do Novo Testamento por excelência é o evento e a pessoa de Jesus Cristo. O acesso Trinitário passa necessariamente pela experiência de Cristo. Em nossa interpretação, a reflexão trinitária de Tracy é evidente uma vez que não se pode falar de nenhuma doutrina cristã sem que ela passe necessariamente pelo evento Cristo. Ademais, o autor assume a identidade de um teólogo cristão católico em diálogo com valores ecumênicos. Cristo é o caminho decisivo, "realidade última", nossa salvação. Mas isso não significa que a realidade de Cristo não dialogue com outras religiões. Na entrevista concedia a Woodward $(2019$, p. 6), Tracy não adota um cristianismo exclusivista, em que, apenas o cristianismo é "dono" do caminho da revelação e da salvação. Por outro lado, critica aqueles que pensam que todas as religiões são a mesma coisa, caminhos diferentes para subir a mesma montanha. Para ele esse pensamento é "fácil demais, simples demais, especialmente se levarmos a sério, em sua compreensão central, o papel decisivo e insubstituível de Jesus Cristo" (WOODWARD, 2019, p. 6).

Em nossa avaliação, tal como Weil, Tracy expõe a necessidade de estabelecer diálogos com outras religiões, mas sem abandonar o centro cristológico-trinitário. Nesse sentido, o cristianismo, enquanto uma religião não é maior do que o Cristo dos evangelhos. As instituições religiosas, não podem ser maiores do que o Verbo encarnado. É assim que uma teologia pública ecoa em tempos que a religião não é tão participante da espera pública. Ao ser perguntado sobre tarefas cumpridas e a cumprir em seu trabalho teológico, Tracy relatou duas intuições significativas: na primeira compartilha uma tarefa cumprida: a percepção de que "sua geração seja a última a falar de teologia cristã apenas em termos de uma das grandes tradições cristãs". A segunda consiste em uma tarefa a cumprir: "aprender tanto quanto possível com as demais tradições religiosas" (WOODWARD, 2019, p. 7).

No diálogo entre os autores acerca da Trindade compreendemos a necessidade de deixarmos que o Deus Trino nos preencha. Deixar ser preenchido por Deus é um ato de esvaziamento e não-leitura. Ao falar de Deus necessitamos ter em mente que sua revelação, por meio da Palavra e do Espírito direciona-se amorosamente a toda criação, a todos nós como uma harmonia sobrenatural. Às vezes, por meio da amizade-proximidade. Outras vezes pela amizade-distância. Como insistia Weil, "o silencio é a palavra secreta de Deus" e "Cristo é o sorriso de Deus".

Em resposta às duas questões centrais levantadas na introdução deste artigo, podemos falar de Deus porque ele fala conosco por meio de uma amizade sobrenatural. Contudo, o nosso falar é sempre cativo à vontade dele, que deseja que todos o conheçam e cheguem ao conhecimento da 
verdade (1Tm 2,1-4). E essa verdade, revelada na cruz, como mostraram os autores apresentados, é a Palavra, o Mediador que nos aproxima de Deus. Podemos concluir com isso que é Deus quem nos busca. É Deus, e somente Ele, quem pode nos amar de maneira graciosa, verdadeira, excessiva e infinita. Então, nossa capacidade de amar a Deus e ao outro não é algo natural. É sobrenatural. Se podemos falar desse amor é porque primeiro, o experimentamos. $\mathrm{O}$ amor e a amizade que Deus estabelece com o ser humano emana da Trindade Santa que têm a cruz como elemento central e nos convida a participar de um relacionamento de amizade sobrenatural, pois com efeito,

não há, não pode haver outra relação do homem com Deus a não ser o amor. Aquilo que não é amor não é relação com Deus. O objeto que convém ao amor é Deus, e qualquer homem que ame outra coisa que não Deus engana-se, erra, como quando se corre na direção de um desconhecido na rua porque se julga tratar-se de um amigo (Weil, 2006, p. 87).

\section{Referências}

BÍBLIA Tradução ecumênica. São Paulo: Loyola, 1994.

BINGEMER, M. C. L. (Org.). Simone Weil e o encontro entre as culturas. São Paulo: Paulinas, 2009.

COENEN, L.; BROWN, C. Dicionário Internacional de Teologia do Novo Testamento. São Paulo: Vida nova, 2000. v. 1, p. 113.

GABELIERRI, E. Être et don: Simone Weil et la philosophie. Paris: Peeters Louvain, 2003.

GABELIERRI, E. Enraizamento e encarnação: dimensões do diálogo intercultural e inter-religioso em Simone Weil. In: BINGEMER, M. C. L. Simone Weil e o encontro entre as culturas. Rio de Janeiro: PUC-Rio, 2009.

PÉTREMENT, S. Vida de Simone Weil. Madrid: Trotta, 1997.

PLATÃO. Timeu-Crítias: Coimbra: Centro de Estudos Clássicos e Humanísticos, 2011. (Colecção Autores Gregos e Latinos).

PUENTE, F. R. Exercícios de Atenção: Simone Weil, leitora dos gregos. São Paulo: Loyola, 2013.

TRACY, D.; LASH, N. Reflexões teológicas conclusivas. In: COLLINS, J.; ALTNER, G.; GILKEY, L.(Orgs.). Teologia e cosmologia. Concilium, Petrópolis, n. 185, v. 6, p. 123-129, 1985. Editorial.

TRACY, D. O Deus da história e o Deus da psicologia. Concilium, Petrópolis, v. 5, n. 249, p. 126-132, 1993.

TRACY, D. Forma e fragmento: a recuperação do Deus escondido e incompreensível. In: GIBELLINI, R. (Ed.). Perspectivas teológicas para o século XXI. São Paulo: Santuário, 2005a. p. 227-278.

TRACY, D. O Deus oculto: o resgate da apocalíptica. In: NEUTZLING, I. A teologia na Universidade. São Leopoldo: Unisinos, 2005b. p. 85-97. 
TRACY, D. A imaginação analógica: a teologia cristã e a cultura do pluralismo. São Leopoldo: Unisinos, 2006. (Coleção Theologia Pública 7).

TRACY, D. Simone Weil et l'impossible. Une pensée radicale de la religion et de culture. In: LUSSY, Florence (Dir.). Simone Weil: Sagesse et grâce violente. Montrouge: Bayard, 2009 p. 273-294.

TRACY, D. Trinitarian Theology and Spirituality: Retrieving William of St. Thierry for Contemporary Theology. In: WOZNIAK R. J.; MASPERO G. (Eds.). Rethinking Trinitarian Theology: Disputed Questions And Contemporary Issues in Trinitarian Theology. New York: T \&T Clark, 2012, p. 387-422.

TRACY, D. Simone Weil: Le masque et la personne. In: L'Herne Simone Weil. Paris: L'Herne, 2014. v. 105, p. 301-306.

TRACY, D. Martin Luther's Deus Theologicus. In: MAŁYSZ, P. J; NELSON D. R. (Ed.). Luther refracted: The reformer's ecumenical legacy. Minneapolis: Fortress 2015. p. 105-140.

VILELA-PETIT, M. Simone Weil et les tragiques grecs. In L'Herne Simone Weil. Paris: L'Herne, 2014, p. 216.

WEIL, S. Intuitions pré-chrétiennes. Paris: Fayard, 1985

WEIL, S. Espera de Deus. São Paulo: ECE, 1987.

WEIL, S. Pensamentos desordenados acerca do amor de Deus. São Paulo, ECE, 1991.

WEIL, S. A gravidade e a graça. São Paulo: Martins Fontes, 1993.

WEIL, S. A fonte grega. Lisboa: Cotovia, 2006.

WEIL, S. Carta a um religioso. Petrópolis: Vozes, 2016.

WEIL, S. Oeuvres Complètes IV, 2. Écrits de Marseille: Grèce, Inde, Occitanie (19411942). Paris: Gallimard, 2009.

WOODWARD, k. L. In praise of fragments: an interview with David Tracy. Commonweal, 25 set. 2019. Disponível em: <https://www.commonwealmagazine.org/ praise-fragments>. Acesso em: nov. 2019.

Artigo submetido em 16.12.2019 e aprovado em 08.04.2020.

Tiago de Freitas Lopes é Doutor em Teologia Sistemática pela Faculdade Jesuíta de Belo Horizonte (FAJE-2019), pesquisador no Grupo de Pesquisa Estudos em Cristologia na mesma instituição. Professor e Capelão no Colégio Batista Mineiro, da Rede Batista de Educação. Orcid.org/0000-0001-9728-6292. E-mail: tiagodefreitasl@gmail.com

Endereço: Rua Graça Aranha 82, apt.o 206

Bairro Santa Branca

31565-200 Belo Horizonte - MG 